\title{
The Impact of Accounting Conservatism and Voluntary Disclosure on the Cost of Capital of Industrial Companies in Jordan
}

\author{
Heba S Warad ${ }^{1} \&$ Mamoun M. Al-Debi'e ${ }^{2}$ \\ ${ }^{1}$ Jordan Atomic Energy Commission, Jordan \\ ${ }^{2}$ Professor of Accounting and Finance, The University of Jordan, Amman-Jordan 11942 \\ Correspondence: Heba S Warad, Jordan Atomic Energy Commission, Jordan
}

Received: December 28, 2016

Accepted: January 25, 2017

Online Published: January 26, 2017

doi:10.5430/afr.v6n1p102

URL: http://dx.doi.org/10.5430/afr.v6n1p102

\begin{abstract}
This study aims at examining the impact of accounting conservatism and voluntary disclosure on the cost of capital of industrial companies in Jordan during the period (2009-2013). Panel OLS regression analysis was employed to test the hypotheses of the study. The results of the full sample model revealed that accounting conservatism and voluntary disclosure have significant negative impacts on the firms' cost of capital.

Furthermore, the results of the sub-samples which distinguish between large and small, as well as between high and low leverage firms showed that the sub-sample of large and small firms conforms to the full sample results. Across the sub-sample of high leverage firms, the results showed that only voluntary disclosure has a significant negative impact on the firm's cost of capital. On the other hand, only accounting conservatism has a significant negative impact on the firm's cost of capital across the sub-sample of low leverage firms.
\end{abstract}

Keywords: Accounting conservatism, Voluntary disclosure, Cost of capital, Cost of equity, Cost of debt, Financial leverage, Firm size

\section{Introduction}

Many prior studies have examined the impact of conservatism and voluntary disclosure on the cost of capital. (Bagnoli \& Watts, 2005) argued that in the presence of asymmetric information, only a conservative accounting choice can be used in order to infer management's private information. (Guay \& Verrecchia, 2007) indicated that to obtain complete disclosure, a manager will act in response to a financial reporting system that requires timely information about low realizations. (Bertomeu, Beyer, \& Dye, 2011; Guay \& Verrecchia, 2007) argued that a firm's capital structure and disclosure policy simultaneously determine its capital cost, since they jointly identify the degree of information asymmetry between outsiders and insiders. This continuing information asymmetry in turn determines the investors' prospective trading losses and hence the firm's cost of capital.

Consequently, this study is directed to explore the interaction between conservatism and the firm's voluntary disclosure, as well as their impact on the cost of capital for all industrial companies listed on Amman Stock Exchange (ASE). Only a few researchers have studied the impact of both accounting conservatism and voluntary disclosure on the cost of capital, particularly in the emerging market. In light of that, the study main objectives can be summarized as follows:

1. To investigate the nature of the relationship between accounting conservatism, voluntary disclosure and cost of capital.

2. To examine the impact of firm size and financial leverage as control variables on the cost of capital.

In order to examine the impact of accounting conservatism and voluntary disclosure on the cost of capital, pooled and panel data analysis techniques were implemented, where analysis is usually estimated by either fixed effect technique or random effect technique. The results of the full sample model revealed that accounting conservatism and voluntary disclosure have significant negative impacts on the firms' cost of capital.

Furthermore, the results of the sub-samples which distinguish between large and small, as well as between high and low leverage firms showed that the sub-sample of large and small firms conforms to the full sample results. Across the sub-sample of high leverage firms, the results showed that only voluntary disclosure has a significant negative 
impact on the firm's cost of capital. On the other hand, only accounting conservatism has a significant negative impact on the firm's cost of capital across the sub-sample of low leverage firms.

\section{Literature Review}

(Cuadrado-Ballesteros, Garcia-Sanchez, \& Martinez Ferrero, 2016) examined the relation between firm's disclosures and cost of capital by analyzing the essential function of information asymmetry as mediator and their impact on the performance of an efficient capital market. The result suggests that high level of quality disclosure will reduce the cost of capital by reducing the information asymmetry.

(Khalifa \& Ben Othman, 2015) examined the economic results of accounting conservatism in emerging economies, particularly in the region of the Middle East and North Africa by using three models include well-known Basu's (1997) model to assess the presence of conservatism, the effect of conservatively reporting bad news and good news on the cost of equity capital, and disaggregated their measurements of conditional conservatism into conservatism with respect to bad news and conservatism with respect to good news. Their results revealed that both have the same negative impact on the cost of equity capital, which implies that conservatism provides the same amount of information irrespective of the type of news.

(Zare, Heidari, salehi, \& Jourkesh, 2013) examined the influence of conservatism and voluntary disclosure on the cost of capital. They argued that there was a significant relation between conservatism rates and capital cost. Moreover, there was a significant negative relation between firm-specific disclosure and capital cost.

(Zalloum, Zerr, Razaq, \& Said, 2013) aimed at determining the degree of disclosure and accounting conservatism in the annual financial reports of the Jordanian companies listed in Amman Stock Exchange (in the services and industrial sectors). Their findings showed that there was no full compliance with disclosure according to the disclosure index. Regarding conservatism, results indicated lack of compliance with accounting conservatism during preparing the financial statements.

(Lara, Osma, \& Penalva, 2011) investigated the relationship between conditional conservatism and firm's cost of equity capital by using asset-pricing test to study whether more conditionally conservative firms gain lower expected returns and by analyzed the relation between conditional conservatism and implied cost of capital as a proxy to estimate the cost of equity capital. The outcomes of their study showed that there is a significant adverse relationship between conditional conservatism and the cost of equity capital.

(Articah \& Clarkson, 2010) examined mutual influence of disclosure and conservatism on the cost of equity capital. They concluded that there is an adverse association between conservatism and cost of equity capital. They further found that conservatism regularly declines the improvement of the firm's information environment. They argued that the signaling benefits of conservatism in the cost of equity capital reduce in environments where there is low information asymmetry.

(Kothari, Li, \& Short, 2009) investigated the impact of disclosure content by management analysts and business press on cost of capital. They classified disclosure as favorable or unfavorable based on the analysis of each content. They found that in case of favorable disclosure the firm's cost of capital, stock return volatility and deception in analysts' earnings decline significantly.

(Chan, Lin, \& Strong, 2009) conducted a study to investigate the relationship between both conditional and unconditional accounting conservatism and the cost of equity capital. their study applied the Ohlson and Juettner-Nauroth model to measure the cost of equity capital and employed a regression model to estimate the relation between the cost of equity capital and accounting conservatism. The results indicated that unconditional conservatism is associated with higher quality of accounting information and lower cost of equity capital, conditional conservatism was associated with lower quality of accounting information and higher cost of equity capital. The findings also implied that conservative accounting signals information to investors on the quality of a firm's current and future earnings.

(Bertomeu, Beyer, \& Dye, 2011) developed a model of external financing that jointly determines a firm's capital structure, its voluntary disclosure policy and its cost of capital. Their model predicts in equilibrium a negative association between the firm's cost of capital and the extent of information disclosed voluntarily. This negative association is attributable to the fact that both the firm's equilibrium cost of capital and its disclosure policy are linked to volatility. 
(Al-Shiab, 2008) investigated empirically whether adopting the International Financial Reporting Standards by Jordanian companies, Dickey-Fuller and Johansen Co-integration tests were applied. Results indicated that none of the independent variables significantly influenced the cost of equity capital.

(Gietzmann \& Ireland, 2005) examined the relationships between timely disclosure, cost 11 of equity capital and accounting choice. And, they analyzed a sample of IT industry firms making strategic disclosures over an 11-year period. The results indicated that there is a significant negative relationship between timely disclosure and cost of capital. Furthermore, there is a significant positive relationship between accounting choice and cost of capital. Finally, the findings indicated the existence of a negative relationship between timely disclosure and cost of capital only for aggressive firms; whereas there is no relationship between disclosure and cost of capital in conservative firms.

(Francis, LaFond, Olsson, \& Schipper, 2004) investigated the relation linking cost of equity capital and seven characteristics of earnings. They used the target price method (rDIV) as a primary gauge of the cost of equity. They also used two alternative measures (Easton, 2004) PEG, rPEG and rMPEG measures and recognized four accounting-based characteristics as well as three market-based attributes. They observed that accounting-based earnings' characteristics explain more of the cross-sectional differences in cost of equity capital than market-based characteristics do, but they failed to find a guide for a relation between cost of equity and their Basu's (1997) proxy as a gauge of conservatism.

(Gietzmann \& Trombetta, 2003) showed that accounting conservatism acts as a substitute for voluntary disclosure, given that voluntary disclosure reduces the cost of equity capital. They found a significant negative relationship between timely disclosure and cost of capital. They showed that this relationship persists irrespective of whether the accounting choice is controlled or not. They further showed that there is a significant negative relationship between the accounting choice and cost of capital. Companies which make aggressive accounting choices have higher costs of capital. Finally, they showed that the negative relationship between timely disclosure and cost of capital exists only for aggressive firms; whereas there is no relationship between disclosure and cost of capital in conservative firms.

(Botosan, 1997) examined the relation linking disclosure level quality and cost of equity capital by regressing firm-specific estimates of cost of capital on market beta. The researcher constructed a measure of disclosure level by using a constructed index and a measure similar to that of Claus and Thomas (RCT) to measure the cost of equity. The results indicates that greater disclosure is linked with lower cost of capital for subset firms with low following, but the association for firms with high following can't be detected.

\section{Study Hypotheses}

In order to achieve the objectives of the study, and based on previous literature, these hypotheses of the study were formulated as follows:

\subsection{The Two Main Hypotheses are:}

$\mathrm{MH}_{1}$ : Accounting conservatism has no impact on the weighted average cost of capital (WACC) of industrial companies in Jordan.

$\mathrm{MH}_{2}$ : Voluntary disclosure has no impact on the weighted average cost of capital (WACC) of industrial companies in Jordan.

\subsection{The Secondary Hypotheses are:}

$\mathrm{SH}_{1}$ : Company size as an intervening variable has no impact on accounting conservatism of industrial companies in Jordan.

$\mathrm{SH}_{2}$ : Company size as an intervening variable has no impact on voluntary disclosure of industrial companies in Jordan.

$\mathrm{SH}_{3}$ : Financial leverage as an intervening variable has no impact on accounting conservatism of industrial companies in Jordan.

$\mathrm{SH}_{4}$ : Financial leverage as an intervening variable has no impact on voluntary disclosure of industrial companies in Jordan.

\section{Study Sample and Period}

A sample of industrial companies listed in ASE with publically available annual reports for the period (2009-2013) is used. The final number of companies included in the analysis was (57) companies and (260) firm year observations after deleting the top and bottom $1 \%$ of observations for each of the study variables, as well as the residual scatter 
plots of the observations on each of the study variables. Table (1) presents the number of industrial companies in ASE and reasons that led to their exclusion from the study sample.

Table 1. Industrial Companies Excluded From the Study Sample

\begin{tabular}{|c|c|c|}
\hline Description & Number of companies & Percentage \\
\hline $\begin{array}{l}\text { Total Industrial companies listed In Amman Stock } \\
\text { Exchange. }\end{array}$ & 69 & $100 \%$ \\
\hline Companies Excluded & 12 & $17 \%$ \\
\hline \multicolumn{3}{|l|}{ Reason of exclusion: } \\
\hline $\begin{array}{l}\text { - Companies with incomplete annual reports for the } \\
\text { study period (2009-2013) }\end{array}$ & 5 & $7 \%$ \\
\hline $\begin{array}{l}\text { Companies with Insufficient Data to Compute } \\
\text { Variables included in the Study }\end{array}$ & 7 & $10 \%$ \\
\hline The Study Sample Companies & 57 & $83 \%$ \\
\hline
\end{tabular}

\section{Data Sources}

Data used in this study are mainly taken from the annual reports of the sampled firms for the years (2009-2013). These annual reports are mostly available on the websites of the firms (if any) and the website of ASE. Annual reports of the Jordan Securities Commission were utilized to obtain information related to the stock split and the distribution of stock dividends.

\section{Variables and Their Measurement}

\subsection{The Dependent Variable:}

\subsubsection{Cost of Capital}

The firm's total capital cost is obtained from a weighted average of all capital sources. This average is vastly wellknown as the Weighted Average Cost of Capital (WACC) (Brealey, Myers, \& Allen, 2011: 219). In this study, the dependent variable is the firm's WACC which will be calculated using the following formula:

$$
\mathbf{W A C C}=\mathbf{K}_{\mathbf{e}} * \mathbf{W}_{\text {Equity }}+\mathbf{K}_{\mathbf{d}} * \mathbf{W}_{\text {Debt }}
$$

where,

$\mathrm{K}_{\mathrm{e}}$ : The yield rate expected by equity capital for firm $\mathrm{i}$ in year $\mathrm{t}$.

$\mathrm{W}_{\text {Equity: }}$ Percentage of equity in the capital structure of firm $\mathrm{i}$ in year $\mathrm{t}$.

$\mathrm{K}_{\mathrm{d}}$ : The yield rate expected by debt capital of firm $\mathrm{i}$ in year $\mathrm{t}$.

$\mathrm{W}_{\text {Debt: }}$ Percentage of debt in the capital structure of firm $\mathrm{i}$ in year $\mathrm{t}$.

\subsubsection{Cost of Equity}

Several alternative approaches have been used in prior studies to estimate the cost of equity capital. These approaches can be classified into ex-post approaches and ex-ante approaches.

CAPM, developed by (Sharp, 1964) is considered the most commonly used method to estimate the cost of equity capital. Although this method is criticized when applied in emerging markets, (Harvey, 1995; Estrada, 2001) argued that CAPM supposes that markets are totally efficient to use beta risk in estimating cost of equity capital, while emerging markets do not have this characteristic. In this study, CAPM is used to calculate the cost of equity, since necessary data for its calculation and measurement are available; whereas other methods measure this variable relying on financial analysts' forecasts which are not available in Jordan.

(Lintner, 1965) stated that the expected cost of equity capital of a security $\mathrm{E}\left(\mathrm{R}_{\mathrm{R}}\right)$ equals the rate on a risk-free security plus a risk premium computed by deducting the risk-free rate of interest $\left(\mathrm{R}_{\mathrm{f}}\right)$ from return on market $\left(\mathrm{R}_{\mathrm{m}}\right)$ multiplied by the company's beta as follows:

$$
\mathbf{C O E}_{\mathrm{i}, \mathrm{t}}=\mathbf{R}_{\mathrm{f}}+\text { Beta }_{\mathrm{i}, \mathrm{t}}\left(\mathrm{MR}-\mathbf{R}_{\mathrm{f}}\right)
$$

where,

$\mathrm{COE}_{i, t}:$ Cost of equity for firm $i$ at the end of year $t$.

$R_{f}$ : Risk-free rate (interest rate on treasury bills for year $t$ ). 
Beta $_{\mathrm{i}, \mathrm{t}}$ : Degree of sensitivity to changes in the company's returns as a result of a change in the market returns. It has been calculated by using monthly returns for (60) months for firm i compared with a market return for (60) months. In case that monthly returns for (60) months are not available for a sampled firm, the researcher attempted to use daily returns for (180) days.

MR: Annual compound market return, which will be calculated as the difference between the closing price and the opening price for market index divided by opening price, then monthly returns are compiled to get the annual compound market return by using the following formula:

$$
\mathrm{MR}_{\mathrm{t}}=\prod_{\mathrm{m}=1}^{12}\left(1+\mathrm{MR}_{\mathrm{m}}\right)-1
$$

Beta coefficient can be computed by applying simple linear regression for the following model:

$$
\mathbf{R}_{\mathrm{mi}}=\mathbf{A}+\boldsymbol{\beta}_{\mathrm{i}} \mathbf{M R}_{\mathrm{m}}+\mathbf{e}
$$

where,

$\mathrm{R}_{\mathrm{mi}}$ : Monthly return for firm i for (60) months at the beginning of year $t, \mathrm{R}_{\mathrm{mi}}$ will be computed by using the following formula:

$$
\mathbf{R}_{\mathrm{mi}}=\mathbf{P}_{\mathrm{st}}-\mathbf{P}_{\mathrm{st}-1} / \mathbf{P}_{\mathrm{st}-1}
$$

where,

$\mathrm{P}_{\mathrm{st}}$ : Closing price for firm's share in month t.

$\mathrm{P}_{\mathrm{st}-1}$ : Closing price for firm's share in month $\mathrm{t}-1$.

$\mathrm{MR}_{\mathrm{m}}$ : Monthly market return for (60) months at the beginning of year $\mathrm{t}, \mathrm{MR}_{\mathrm{m}}$ will be computed by the following formula:

$$
\mathrm{MR}_{\mathrm{m}}=\mathbf{P}_{\mathrm{Mt}}-\mathbf{P}_{\mathrm{Mt}-1} / \mathbf{P}_{\mathrm{Mt}-1}
$$

where,

$\mathrm{P}_{\mathrm{Mt}}$ : Closing price for market prices in month $\mathrm{t}$.

$\mathrm{P}_{\mathrm{Mt}-1}$ : Closing price for market prices in month $\mathrm{t}-1$.

\subsubsection{Cost of Debt}

Many prior studies, such as those conducted by (Zhu, 2009; Schauten \& Blom, 2006) used the yield on outstanding bonds as a proxy for the cost of debt. Further, plentiful studies of prior literature used S\&P's long-term credit ratings as a proxy for the cost of debt, such as (Altman, 1992; Ashbaugh-Skaife, Collins, \& Lafond, 2006). In this study, cost of debt is measured using the following formula:

$$
\operatorname{COD}_{i, t}=\left[\text { Interest Cost } t_{i, t+1} \div \text { Interest Bearing Debt outstanding }{ }_{i t, t+1}\right] \times[1-\text { Tax Rate }]
$$

where,

$\mathrm{COD}_{\mathrm{i}, \mathrm{t}}$ : Cost of debt for firm $\mathrm{i}$ at the end of year $\mathrm{t}$.

Interest Cost $_{\mathrm{i}, t+1}$ : Interest expense for firm $\mathrm{i}$ at the end of year $\mathrm{t}+1$

Interest Bearing Debt Outstandingit ${ }_{\mathrm{it}, \mathrm{t}+1}$ : Average of debt that requires payment of interest for firm $\mathrm{i}$ between year $\mathrm{t}$ and year $\mathrm{t}+1$.

Debt that requires payment of interest includes: accounts and notes payable, short-term loans, accrued part of long-term loans, long-term loans and corporate bonds.

Tax Rate: according to the income tax law of 1995, industrial companies subjected to $15 \%$ for year 2009, and subjected to 14\% for years 2010, 2011, 2012 and 2013 according to the tax law No. (28) for year 2009.

\subsection{The Independent Variables}

\subsubsection{Accounting Conservatism}

Based on the well-known and widely used measure introduced by (Basu, 1997) the Basu's model of asymmetric timeliness is used to estimate a firm-year measure of conservatism. The Basu's cross-sectional regression is given by the equation:

$$
E A R N_{i, t}=\alpha_{0}+\alpha_{1, i} N E G_{i, t}+\beta_{1, i} R E T_{i, t}+\beta_{2, i} N E G_{i, t} * R E T_{i, t}+\varepsilon_{i, t}
$$


where,

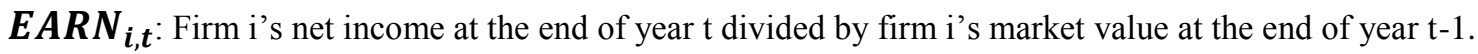

$\boldsymbol{R E} \boldsymbol{T}_{\boldsymbol{i}, \boldsymbol{t}}$ : Monthly compound return for firm i at the end of 30/4 after the end of year $\mathrm{t}$.

$\boldsymbol{N} \boldsymbol{E} \boldsymbol{G}_{\boldsymbol{i}, \boldsymbol{t}}$ : Dummy variable set equal to 1 if the $\boldsymbol{R} \boldsymbol{E} \boldsymbol{T}_{\boldsymbol{i}, \boldsymbol{t}}$ is negative (bad news) and 0 otherwise.

In order to obtain the timeliness of conservatism measure at the firm year level, Khan and Watts specify that both the timeliness of good news (which they refer to as G-Score) and the incremental bad news over good news (which they refer to as C-Score) are linear functions of firm-specific characteristics each year as follows:

$$
\begin{gathered}
\text { G-Score } \equiv \beta_{1}=\mu_{1}+\mu_{2} \operatorname{SIZE~}_{i}+\mu_{3} \mathrm{MTB}_{\mathrm{i}}+\mu_{4} \mathrm{LEV}_{\mathrm{i}} \\
\mathrm{C}-\mathrm{Score} \equiv \beta_{2}=\lambda_{1}+\lambda_{2} \operatorname{SIZE}_{\mathrm{i}}+\lambda_{3} \mathrm{MTB}_{\mathrm{i}}+\lambda_{4} \mathrm{LEV}_{\mathrm{i}}
\end{gathered}
$$

Where,

MTB: Market-to-book ratio calculated as market capitalization divided by book value of equity.

$L E V$ : Leverage defined as long-term and short-term debt deflated by market value of equity.

SIZE: Natural log of market value of equity.

According to (Khan \& Watts, 2009), empirical estimators of $\mu_{i}$ and $\lambda_{i}, i=(1-4)$, are constant across firms, but vary over time. As a result of cross-sectional variation in the firm-year characteristics (SIZE, LEV and MTB), G-Score and C-Score will vary across firms, and those scores will vary over time through intertemporal variation in $\lambda_{i, t}, \mu_{i, t}$ and the firm-year characteristics.

In order to estimate the coefficients within the two equations mentioned above, (Khan and Watts 2009) use the following annual cross-section regression model:

$\mathbf{X}_{\mathrm{i}}=\beta_{1}+\beta_{2} \mathrm{D}_{\mathrm{i}}+\mathbf{R}_{\mathrm{i}}\left(\mu_{1}+\mu_{2} \mathrm{SIZE}_{\mathrm{i}}+\mu_{3} \mathrm{MTB}_{\mathrm{i}}+\mu_{4} \mathrm{LEV}_{\mathrm{i}}\right)+\mathrm{D}_{\mathrm{i}} \mathbf{R}_{\mathrm{i}}\left(\lambda_{1}+\lambda_{2} \mathrm{SIZE}_{\mathrm{i}}+\lambda_{3} \mathrm{MTB}_{\mathrm{i}}+\lambda_{4} \mathrm{LEV}_{\mathrm{i}}\right)+\left(\delta_{1} \mathrm{SIZE}_{\mathrm{i}}+\right.$

$\left.\delta_{2} \mathrm{MTB}_{\mathrm{i}}+\delta_{3} \mathrm{LEF}_{\mathrm{i}}+\delta_{4} \mathrm{D}_{\mathrm{i}} \mathrm{SIZE}_{\mathrm{i}}+\delta_{5} \mathrm{D}_{\mathrm{i}} \mathrm{MTB}_{\mathrm{i}}+\boldsymbol{\delta}_{6} \mathrm{D}_{\mathrm{i}} \mathrm{LEV}_{\mathrm{i}}\right)+\boldsymbol{\varepsilon}_{\mathrm{i}}$.

According to their model, C-Score is the firm year measure of conservatism or bad news over good news, and the total of bad news gained from the sum of C-Score and G-Score. In this context, this study is interested in the C-score as a proxy of accounting conservatism measures (conservatism is increasing with the C-Score).

After estimating this model, C-Score for each firm in each year is obtained as follows:

\subsubsection{Voluntary Disclosure}

$$
C \text {-Score } \mathrm{i}_{\mathrm{t}, \mathrm{t}} \equiv \boldsymbol{\beta}_{2}=\hat{\lambda}_{1}+\hat{\lambda}_{2} \mathrm{SIZE}_{\mathrm{i}, \mathrm{t}}+\hat{\lambda}_{3} \mathrm{MTB}_{\mathrm{i}, \mathrm{t}}+\hat{\lambda}_{4} \mathrm{LEV}_{\mathrm{i}, \mathrm{t}}
$$

This variable will be measured based on voluntary disclosure index, which was constructed by (Haddad, 2005) who examined the influence of voluntary disclosure level on the cost of equity capital by using Jordanian data provided in the annual reports of Jordanian companies. His constructed index list consists of nine categories, which covered a wide range of voluntary information, financial and non-financial items of information, qualitative and quantitative items, as well as historical and future items. In order to measure this variable by the actual score assigned to i firms and a maximum number of applicable items of information, it is required to calculate the level of disclosure for each firm. So, by the unweighted approach used by (Haddad 2005; Haddad, AlShattarat, \& Nobanee, 2009) in their study, a dichotomous scale was used as shown below:

A score of one (1) is assigned when an item of information within the index is disclosed in the firm's annual report. A score of zero (0) is assigned when an item of information within the index is not disclosed in the firm's annual report. Not applicable is assigned when an item within the disclosure index is not applicable to the firm.

\subsection{Control Variables}

Firm size and financial leverage variables were measured as follows:

\subsubsection{Firm Size}

$$
\mathrm{FS}_{\mathrm{i}, \mathrm{t}}=\log \text { of total } \text { assets }_{\mathrm{i}, \mathrm{t}}
$$

where,

Total assets ${ }_{i, t}:$ Total assets of firm $i$ at the end of year $t$. 


\subsubsection{Financial Leverage}

The financial leverage of companies included in this study will be measured by debt-to-asset ratio as shown in the following formula:

$$
\mathbf{F L}_{\mathrm{i}, \mathrm{t}}=\mathbf{T D}_{\mathrm{i}, \mathrm{t}} / \mathbf{T \mathbf { A } _ { \mathrm { i } , \mathrm { t } }}
$$

where,

$\mathrm{FL}_{\mathrm{i}, \mathrm{t}}$ : Debt-to-asset for company $\mathrm{i}$ in year $\mathrm{t}$.

$\mathrm{TD}_{\mathrm{i}, \mathrm{t}}$ : Total debt for company $\mathrm{i}$ at the end of year $\mathrm{t}$.

$\mathrm{TA}_{\mathrm{i}, \mathrm{t}}$ : Total assets for company $\mathrm{i}$ at the end of year $\mathrm{t}$.

\section{Statistical Techniques Used}

To examine the impact of accounting conservatism and voluntary disclosure on the cost of capital, pooled and panel data analysis techniques were implemented, where analysis is usually estimated by either fixed effect technique or random effect technique. According to (Gujarati, 2003) the main advantage of using panel data analysis technique over pooled data analysis technique is helping in generating more variability and efficiency, as well as less collinearity with variables. In order to test random effect model against pooled OLS model, (Breusch \& Pagan, 1980) and Lagrange multiplier (LM) are used under the following null hypothesis:

\section{$\mathrm{H}_{0}$ : zero cross-section variances.}

Thus, if the significance (LM) test leads to the rejection of the null hypothesis, this means that there are individual group effects which are not equal to zero. Moreover, Hausman test was used for the selection between fixed-effect and random- effect methods under the following hypotheses:

\section{$H_{0}$ : random- effect method is more efficient.}

\section{$H_{1}$ : fixed-effect method is more efficient.}

So, the rejection of the null hypothesis indicates that fixed-effect estimations are more appropriate than random-effect estimations, the regression model has been constructed as follows:

$$
\text { WACC }_{\mathrm{it}}=\alpha_{0}+\alpha_{1} \text { CONSERV }_{\mathrm{i}, \mathrm{t}}+\alpha_{2} \text { VDISC }_{\mathrm{i}, \mathrm{t}}+\alpha_{3} \mathrm{FL}_{\mathrm{i}, \mathrm{t}}+\alpha_{4} \mathrm{FS}_{\mathrm{i}, \mathrm{t}}+\varepsilon_{1 \mathrm{i}, \mathrm{t}}
$$

Where,

$\mathrm{WACC}_{\mathrm{i}, \mathrm{t}}$ : Weighted average cost of capital for firm iat the end of year $\mathrm{t}$.

CONSERV $_{\mathrm{i}, \mathrm{t}}$ : Conservatism for firm $\mathrm{i}$ at the end of year $\mathrm{t}$.

VDISC $_{\mathrm{i}, \mathrm{t}}$ : Voluntary disclosure level for firm $\mathrm{i}$ at the end of year $\mathrm{t}$.

$\mathrm{FL}_{\mathrm{i}, \mathrm{t}}$ : Financial leverage for firm $\mathrm{i}$ at the end of year $\mathrm{t}$.

$\mathrm{FS}_{\mathrm{i}, \mathrm{t}}$ : Firm size for firm $\mathrm{i}$ at the end of year $\mathrm{t}$.

$\alpha_{0}, \alpha_{1}, \alpha_{2}, \alpha_{3}, \alpha_{4}$ : Coefficients of regression model.

$\varepsilon_{1 \mathrm{i}, \mathrm{t}}$ : Error term.

\section{Descriptive Statistics}

Table (2) shows the results of descriptive statistics for all study variables before and after deleting outlier observations. The mean Weighted Average Cost of Capital (WACC) indicates that the companies within the study sample have on average a relatively lower level of WACC as an indicator of financial stability. Moreover, the study sample has on average a decrease in accounting conservatism. On the other hand, there is clear variation in the extent of voluntary disclosure. The companies constituting the study sample showed a level of voluntary disclosure with a mean of $26.65 \%$ (median $=25.81 \%$ ). Pearl-Sanitary Paper Converting Company scored the lowest level of voluntary disclosure of $(2.04 \%)$ in the year 2011, while the Arab Potash Company scored the highest level of voluntary disclosure of $(56.45 \%)$ in the year 2013. Statistics regarding firm size and financial leverage as control variables indicate that the companies within the study sample range from small to large, as well as from levered to unlevered companies. 
Table 2. Descriptive Statistics of the Study Variables During (2009-2013)

\begin{tabular}{lcccccccc}
\hline Variables & Percentile & Minimum & Mean & Median & Maximum & Percentile & Std. & $\begin{array}{c}\text { No. of } \\
\text { Obs. }\end{array}$ \\
& $\mathbf{1}$ & & \multicolumn{7}{c}{ Before Removing Outliers } \\
WACC & -.2356 & -.5172 & .03988 & .04207 & .3820 & .2092 & .06121 & 285 \\
CONSERV & -12.50 & -14.09 & .0617 & .3099 & 20.19 & 11.58 & 3.569 & 285 \\
VDISC & .0306 & .0161 & .2659 & .2581 & .5806 & .5645 & .0962 & 285 \\
FS & 5.914 & 5.742 & 7.237 & 7.183 & 9.087 & 9.036 & .5973 & 285 \\
FL & .0048 & .0044 & .3334 & .3048 & 1.071 & 1.000 & .2213 & 285 \\
& & & After Removing Outliers & & & \\
WACC & -.1010 & -.2086 & .04145 & .04190 & .1180 & .1060 & .0333 & 260 \\
CONSERV & -11.225 & -12.307 & -.1494 & .3100 & 10.299 & 7.447 & 2.883 & 260 \\
VDISC & .0276 & .0204 & .2665 & .2581 & .5645 & .5645 & .0925 & 260 \\
FS & 5.952 & 5.796 & 7.227 & 7.184 & 9.046 & 9.015 & .5737 & 260 \\
FL & .0048 & .0047 & .3254 & .3049 & .9447 & .9240 & 2060 & 260 \\
\hline
\end{tabular}

WACC is the weighted average cost of capital $\left(\mathrm{K}_{\mathrm{e}} * \mathrm{~W}_{\text {Equity }}+\mathrm{K}_{\mathrm{d}} * \mathrm{~W}_{\text {Debt }}\right)$; where, $\mathrm{K}_{\mathrm{e}}$ is the cost of equity capital calculated using the capital assets pricing model developed by Sharp (1964). $\mathrm{K}_{\mathrm{d}}$ is the cost of debt calculated as:

$$
\left(\text { COD }_{i, t}=\left[\text { InterestCost }_{i, t+1} \div \text { InterestBearingDebtOutstanding }_{i, t, t+1}\right] \times[1-\text { TaxRate }]\right) \text {. }
$$

CONSERV is the firm-year measure of conditional conservatism obtained using Khan and Watts' (2009) method. VDISC is the voluntary disclosure measured based on voluntary disclosure index constructed by Haddad (2005).FS is the firm size expressed by the natural logarithm of total assets. FL is the financial leverage expressed by the total debt divided by the total assets.

\section{Correlation between Study Variables}

Table (3) reports the Pearson and Spearman correlation coefficients between the study variables. Pearson correlation coefficients are reported above the diagonal, whereas Spearman correlation coefficients are reported below the diagonal.

The results presented in table (3) show that cost of capital and accounting conservatism are negatively correlated. This means that an increase in accounting conservatism reduces the firm's cost of capital. Moreover, the cost of capital and voluntary disclosure are negatively correlated, which means that the higher the score of voluntary disclosure, the lower the amount of firm's cost of capital. The Control variables; firm size and (financial leverage) have negative (positive) correlation, respectively. This means that the larger the firm size, the lower the amount of firm's cost of capital, and higher cost of capital is correlated with higher financial leverage.

Table 3. Pearson and Spearman correlation between study variables

\begin{tabular}{lccccc}
\hline & WACC & CONSERV & VDISC & FS & FL \\
\hline \multirow{2}{*}{ WACC } & & $-.124^{*}$ & $-.231^{* * *}$ & $-.238^{* * *}$ & .099 \\
\multirow{2}{*}{ CONSERV } & & $(\mathbf{0 . 0 4 6})$ & $(.000)$ & $(.000)$ & $(.112)$ \\
& $-.192^{* *}$ & & -.100 & $-.123^{*}$ & $.265^{* *}$ \\
VDISC & $(.002)$ & & $(.109)$ & $(.047)$ & $(.000)$ \\
& -.095 & -.057 & & $.347^{* *}$ & -.011 \\
FS & $(.127)$ & $(.361)$ & & $(.000)$ & $(.864)$ \\
& $-.149^{*}$ & $-.123^{*}$ & $.182^{* *}$ & & $.200^{* * *}$ \\
FL & $(.016)$ & $(.047)$ & $(.003)$ & & $(.001)$ \\
& $.176^{* *}$ & .096 & .058 & $.264^{* *}$ & \\
\hline
\end{tabular}

WACC is the weighted average cost of capital $\left(\mathrm{K}_{\mathrm{e}} * \mathrm{~W}_{\text {Equity }}+\mathrm{K}_{\mathrm{d}} * \mathrm{~W}_{\text {Debt }}\right)$; where, $\mathrm{K}_{\mathrm{e}}$ is the cost of equity capital 
calculated using the capital assets pricing model developed by Sharp (1964). $\mathrm{K}_{\mathrm{d}}$ is the cost of debt calculated as $\left(\operatorname{COD}_{i, t}=\left[\right.\right.$ InterestCost $_{i, t+1} \div$ InterestBearingDebtOutstanding $\left._{i, t, t+1}\right] \times[1-$ TaxRate $\left.]\right)$. CONSERV is the firm-year measure of conditional conservatism obtained using Khan and Watts' (2009) method. VDISC is the voluntary disclosure measured based on voluntary disclosure index constructed by Haddad (2005). FS is the firm size expressed by the natural logarithm of total assets. FL is the financial leverage expressed by the total debt divided by the total assets.

**Correlation is significant at the 0.01 level (2-tailed).

*Correlation is significant at the 0.05 level (2-tailed).

(Mo, 2015) arguing that the relation between accounting conservatism and voluntary disclosure is not statistic, but dynamic, his empirical results revealed that less conservative firms are more likely to increase the voluntary disclosure level. As shown in Table (3), the correlation coefficients between accounting conservatism and voluntary disclosure are negative, but insignificant. Moreover, accounting conservatism and firm size are negatively correlated. (Khan \& Watts, 2009) argued that firms with larger size have to be less conservative. Voluntary disclosure and firm size are positively correlated, since lower cost of information for large companies may provide the manager with an incentive to disclose more information. (Depoers, 2000; Dumontier \& Raffournier, 1998) argued that political costs are positively related with large firm size, thus; large firms should apply international accounting standards more than smaller firms. On the other hand, accounting conservatism and financial leverage are positively correlated. In contrast, the correlation coefficient between voluntary disclosure and financial leverage is insignificant.

As shown in Table (3), it can be seen that most of the correlation coefficients between the independent and control variables are fairly small, which means that multi-collinearity does not constitute a problem in interpreting the results of the regression analysis. Table (4) presents the results of two multi-collinearity tests; the variance inflation factor and tolerance values are less than (10) and (1), respectively, which provides evidence on that multi-collinearity does not constitute a problem in interpreting the results of the regression analysis.

Table 4. Variance Inflation Factor Test Results

Independent Variable

\section{WACC: Dependent Variable}

Collinearity Statistics

\begin{tabular}{lcc} 
& Tolerance & VIF \\
\hline CONSERV & 0.896 & 1.116 \\
VDISC & 0.872 & 1.147 \\
FS & 0.816 & 1.226 \\
FL & 0.870 & 1.149
\end{tabular}

CONSERV is the firm-year measure of conditional conservatism obtained using Khan and Watts' (2009) method. VDISC is the voluntary disclosure measured based on voluntary disclosure index constructed by( Haddad, 2005). FS is the firm size expressed by the natural logarithm of total assets. FL is the financial leverage expressed by the total debt divided by the total assets.

\section{Study Results}

The P-value of Lagrange multiplier test (LM) is significant, as shown in Table (5), which means that the panel OLS analysis technique is more appropriate than the pooled OLS technique. Thus, Hausman test should be run to choose between random-effect method and fixed-effect method. According to Hausman test, the results show that the random-effect method is found to be the preferred one, since Hausman test is found to be insignificant.

\subsection{Results of Main Research Hypotheses Test}

The results in Table (5) indicate that accounting conservatism has a significant negative impact on the firm's cost of capital. This result is consistent with the signaling theory derived by (Spence, 1973) which means that Jordanian companies use conservative accounting policy as a sign for quality; precisely positive quality; hence higher quality decreases the information risk for the company which in turn leads to decrease the firm's cost of capital. This result is supported by (Artiach \& Clarkson, 2011) who argued that there is an adverse association between conservatism and cost of capital. They further found that conservatism regularly declines the improvement of the firm's information environment. It is also supported by the results of (Khalifa \& Ben Othman, 2015; Zare et al,. 2013; Lara et al., 2011; Gietzmann \& Trombetta, 2003). Thus, this result leads to the rejection of the first main null hypothesis in this study. 
The results also show that voluntary disclosure has a significant negative impact on the firm's cost of capital, which means that the higher the information disclosure, the lower the firm's cost of capital. This adverse impact is based on the liquidity and assessment risk attitudes. According to (Poshakwale \& Courtis, 2005) higher information disclosure decreases the investors' ambiguities, thereby enabling them to obtain stable good results, which in turn enables the company to absorb long-term investments, since these investments seem better than short-term ones, which positively influences the firm's market price and supply capacity and therefore decreases, the cost of capital. This result is consistent with the results of (Zare et al., 2013; Articah \& Clarkson, 2010; Kothari et al., 2009; Bertomeu et al., 2011; Gietzmann \& Ireland, 2005; Gietzmann \& Trombetta, 2003; Botosan, 1997). Thus, this result leads to the rejection of the second main null hypothesis in this study.

Table 5. Pooled and panel OLS regression results for industrial companies (2009-2013), 260 firm-year observations

\begin{tabular}{lccc}
\hline \multirow{2}{*}{ Estimation technique } & Pooled OLS & Fixed-Effect & Ranel OLS \\
\hline Constant & 5.059 & 0.9497 & 4.441 \\
& $(0.000)$ & $(0.343)$ & $(0.000)$ \\
CONSERV & -3.693 & -4.476 & -4.344 \\
VDISC & $(0.000)^{* *}$ & $(0.000)$ & $(0.000)^{* *}$ \\
& -2.659 & -1.8053 & -2.289 \\
FS & $(0.008)^{* *}$ & $(0.072)$ & $(0.022)^{*}$ \\
& -3.899 & -0.6898 & -3.097 \\
FL & $(0.000)^{* *}$ & $(0.4911)$ & $(0.002)^{* *}$ \\
& 3.333 & 1.8588 & 2.866 \\
LM test & $(0.001)^{* *}$ & $(0.064)$ & $(0.004)^{* *}$ \\
& 35.433 & & \\
Hausman test & $(0.0000)^{* *}$ & & 2.542 \\
Adjusted R & & & $(0.6370)$ \\
F-statistic & & & 0.1137 \\
Prob.(F-statistic) & 0.1325 & & 9.310 \\
Durbin-Watson & 10.890 & & $(0.000)$ \\
\hline The & $(0.000)$ & & $2.010^{\mathrm{a}}$ \\
\hline
\end{tabular}

The table reports the results of running the pooled and panel regressions of the model:

$$
\text { WACC }_{\mathrm{i}, \mathrm{t}}=\alpha_{0}+\alpha_{1} \text { CONSERV }_{\mathrm{i}, \mathrm{t}}+\alpha_{2} \text { VDISC }_{\mathrm{i}, \mathrm{t}}+\alpha_{3} \mathrm{FS}_{\mathrm{i}, \mathrm{t}}+\alpha_{4} \mathrm{FL}_{\mathrm{i}, \mathrm{t}}+\varepsilon_{1 \mathrm{i}, \mathrm{t}} .
$$

WACC is the weighted average cost of capital $\left(\mathrm{K}_{\mathrm{e}} * \mathrm{~W}_{\text {Equity }}+\mathrm{K}_{\mathrm{d}} * \mathrm{~W}_{\text {Debt }}\right)$; where, $\mathrm{K}_{\mathrm{e}}$ is the cost of equity capital calculated using the capital assets pricing model developed by Sharp (1964). $\mathrm{K}_{\mathrm{d}}$ is the cost of debt calculated as $\left(C O D_{i, t}=\left[\right.\right.$ InterestCost $_{i, t+1} \div$ InterestBearingDebtOutstanding $\left.{ }_{i, t . t+1}\right] \times[1-$ TaxRate $\left.]\right)$. CONSERV is the firm-year measure of conditional conservatism obtained using Khan and Watts' (2009) method. VDISC is the voluntary disclosure measured based on voluntary disclosure index constructed by Haddad (2005). FS is the firm size expressed by the natural logarithm of total assets. FL is the financial leverage expressed by the total debt divided by the total assets.

The number in parentheses is the $\mathrm{P}$-value.

** Significant at the 0.01 level (2-tailed).

* Significant at the 0.05 level (2-tailed).

${ }^{a}$ According to Gujarati (2003), Durbin-Watson test to detect serial correlation is acceptable when its value lies between $(1.5<$ Durbin-Watson <2.5). So, it is correct to use the regression model represented in (Table 5). 


\subsection{Results of Secondary Research Hypotheses Test}

Using the same methodology of (Hamdan, 2011) the full sample was partitioned according to firm size (large and small), through comparing the mean of total assets of every individual firm during (2009-2013) with the general mean of all firms' assets included in the study. Thus, if the mean of the total assets of the company exceeds the general mean, the company is considered large, otherwise it is considered small. The number of large firms was (12), while the number of small firms was (45). Also, the full sample was portioned by using $60 \%$ and $40 \%$ percentiles to represent high levered and low levered firms, respectively. Accordingly, the number of observations for the two sub-samples was equal to (104).

The results in Table (6) indicate that across large and small size firm sub-samples, it is confirmed that CONSERV and VDISC have significant negative impacts on the WACC. (Minton \& Wruck, 2001) documented that larger firms are less likely to have accounting conservatism policy, since the cost of external financing for larger firms is lower than for smaller firms; hence they don't have an incentive to shelve cash. This supports the picking order theory, since firms use internal sources and then have external sources. (Hamdan, 2012) examined the factors affecting the level of accounting conservatism in Jordanian companies using the Basu's model. His results showed that the variable $\left(\mathrm{R}_{\mathrm{i}, \mathrm{x}} \times \mathrm{DR}_{\mathrm{i}, \mathrm{t}}\right)$ which represents the incremental bad news over good news (conservatism) was statistically significant in small firms and insignificant in large firms. He concluded that Jordanian smaller firms are more conservative than bigger ones, while theoretically large firms adhere to accounting conservatism to avoid political costs, financial analysts and governmental alertness. His conclusion was reinforced through the fact that adjusted $\mathrm{R}^{2}$ was larger in his model for small firms with a percentage of $(38.1 \%)$, while adjusted $\mathrm{R}^{2}$ in his model was equal to (17.7\%) for large firms. Results in Table (5) are consistent with those of (Hamdan, 2012) showing that the adjusted

$\mathrm{R}^{2}$ for small firms was equal to (27.69\%), which is clearly higher than adjusted $\mathrm{R}^{2}$ for large firms which was equal to (18.83\%). This result is also consistent with (Khan \& Watts, 2009).

Table 6. Pooled and panel OLS regression results for sub-sample represented by large and small firm size

\begin{tabular}{|c|c|c|c|}
\hline \multirow{2}{*}{ Estimation technique } & \multirow{2}{*}{$\begin{array}{c}\text { Large Size Sample } \\
\text { Pooled OLS }\end{array}$} & \multicolumn{2}{|c|}{ Small Size Sample } \\
\hline & & Pooled OLS & Fixed- Effect \\
\hline \multirow{2}{*}{ Constant } & 5.027 & 7.098 & 8.275 \\
\hline & $(0.000)$ & $(0.000)$ & $(0.000)$ \\
\hline \multirow{2}{*}{ CONSERV } & -2.175 & -2.006 & -4.233 \\
\hline & $(0.034) * *$ & $(0.046) *$ & $(0.000) * *$ \\
\hline \multirow{2}{*}{ VDISC } & -3.533 & -0.440 & -2.959 \\
\hline & $(0.000) * *$ & $(0.660)$ & $(0.003) * *$ \\
\hline \multirow{2}{*}{ LM test } & 0.2343 & 33.374 & \\
\hline & $(0.628)^{b}$ & $(0.000)^{\mathrm{c}}$ & \\
\hline \multirow{2}{*}{ Hausman test } & & & 19.466 \\
\hline & & & $(0.000)$ \\
\hline Adjusted $R^{2}$ & 0.1883 & 0.003 & 0.2769 \\
\hline F-statistic & 7.151 & 2.101 & 2.706 \\
\hline Prob.(F-statistic) & $(0.001)$ & $(0.124)$ & $(0.000)$ \\
\hline
\end{tabular}

The table reports the results of running the pooled and panel regressions according to portioning the full sample into large and small firms.

$$
\text { WACC }_{i, t}=\alpha_{0}+\alpha_{1} \operatorname{CONSERV}_{i, t}+\alpha_{2} \operatorname{VDISC}_{i, t}+\varepsilon_{1, t,} .
$$

WACC is the weighted average cost of capital $\left(\mathrm{K}_{\mathrm{e}} * \mathrm{~W}_{\text {Equity }}+\mathrm{K}_{\mathrm{d}} * \mathrm{~W}_{\text {Debt }}\right)$; where, $\mathrm{K}_{\mathrm{e}}$ is the cost of equity capital calculated using the capital assets pricing model developed by Sharp (1964). $\mathrm{K}_{\mathrm{d}}$ is the cost of debt calculated as:

$$
\left(\operatorname{COD}_{i, t}=\left[\text { InterestCost }_{i, t+1} \div \text { InterestBearingDebtOutstanding }{ }_{i, t, t+1}\right] \times[1-\text { TaxRate }]\right) .
$$

CONSERV is the firm-year measure of conditional conservatism obtained using Khan and Watts' (2009) method. VDISC is the voluntary disclosure measured based on voluntary disclosure index constructed by Haddad (2005). 
The number in parentheses is the $\mathrm{P}$-value.

** Significant at the 0.01 level (2-tailed),

* Significant at the 0.05 level (2-tailed).

${ }^{\mathrm{b}}$ According to (LM) test, the null hypothesis for pooled OLS regression for the large size sample is accepted, since the P-value is equal to (0.628).

${ }^{c}$ According to (LM) test, the null hypothesis for pooled OLS regression for the small size sample is rejected, since the P-value is equal to (0.000). Thus, Hausman test should be run. According to Hausman test, the results revealed that the fixed-effect OLS regression is appropriate for the small firms' sample, since the null hypothesis is rejected.

On the other hand, the results revealed that, within large and small firms, VDISC has a negative significant impact on WACC, But, according to Table (7) which represents the means and medians of voluntary disclosure according to large size and small size, it is shown that larger companies have a higher level of voluntary disclosure $($ mean $=0.3116$, median $=0.2984)$ than smaller firms $($ mean $=0.2546$, median 0.2581). This result supports the notion that disseminating and collecting more information is a costly exercise, where larger firms may have the ability to bear such high costs, while smaller firms may be hesitant to provide additional disclosure which might put them at a disadvantageous competition (Firth, 1979). Many studies support this argument, such as (Hossain, Perera, \& Rahman, 1995; Ahmed \& Nicholls, 1994).Thus, this result leads to the rejection of the first and the second secondary null hypotheses in this study.

Table 7. Means and Medians of Voluntary Disclosure for Large and Small Size Firms

\begin{tabular}{lccccc}
\hline & Mean & Median & Std. Deviation & No. of Obs. & No. of Firms \\
\hline Large Firms & $\mathbf{0 . 3 1 1 6}$ & $\mathbf{0 . 2 9 8 4}$ & $\mathbf{0 . 1 3 5 1}$ & 54 & 12 \\
Small Firms & $\mathbf{0 . 2 5 4 6}$ & $\mathbf{0 . 2 5 8 1}$ & $\mathbf{0 . 0 7 3 5}$ & 206 & 45 \\
\hline
\end{tabular}

The results in Table (8) indicate that across the sub-sample of high leverage firms, VDISC has a significant negative impact on the WACC, while CONSERV has an insignificant impact. On the other hand, the results revealed that across the sub-sample of low leverage firms, CONSERV has a significant negative impact on the WACC, while VDISC has an insignificant impact. The result pertinent to the impact of CONSERV on WACC across low leverage firms is consistent with that of Hamdan's (2012) study, which revealed that low leverage firms (as a proxy of debt contract) in Jordan were more conservative than high leverage firms. Thus, this result leads to the rejection of the third secondary hypothesis.

According to (Jensen \& Meckling, 1976) managements in high leverage firms seek to reduce their monitoring costs through adopting various types of voluntary disclosure. Also, high leverage firms will adopt more timely information in order to reduce the long-term creditors' suspicion about the firm's ability to pay its obligations (Schipper, 1991). This result is consistent with that found by (Haniffa \& Rashid, 2005). Thus, this result leads to the rejection of the fourth secondary hypothesis. 
Table 8. Pooled and panel OLS Regression Results for Sub-sample Represented by High and Low Financial Leverage

\begin{tabular}{lcccc}
\hline \multirow{2}{*}{ Estimation technique } & \multicolumn{2}{c}{ High Leverage Firms } & \multicolumn{2}{c}{ Low Leverage Firms } \\
& Pooled OLS & Random-Effect & Pooled OLS & Random-Effect \\
\hline \multirow{2}{*}{ Constant } & 6.343 & 6.503 & 6.825 & 6.637 \\
& $(0.000)$ & $(0.000)$ & $(0.000)$ & $(0.000)$ \\
CONSERV & 0.675 & 0.1886 & -3.465 & -3.370 \\
& $(0.501)$ & $(0.850)$ & $(0.000)^{* *}$ & $(0.001)^{* *}$ \\
VDISC & -1.634 & -2.138 & -1.120 & -1.089 \\
& $(0.105)$ & $(0.0349)^{*}$ & $(0.265)$ & $(0.278)$ \\
LM test & 20.634 & & 8.465 & \\
& $(0.000)^{\mathrm{d}}$ & & $(0.003)^{\mathrm{e}}$ & \\
Hausman test & & 4.427 & & 2.157 \\
Adjusted $\boldsymbol{R}^{2}$ & & $(0.109)$ & & $(0.340)$ \\
$\boldsymbol{F}$-statistics & 0.0143 & 0.0284 & 0.0930 & 0.0930 \\
Prob.(F-statistic) & 1.747 & 2.505 & 6.284 & 6.284 \\
Durbin-Watson & $(0.174)$ & $(0.086)$ & $(0.002)$ & $(0.002)$ \\
\hline
\end{tabular}

The table reports the results of running the pooled and panel regressions according to portioning the full sample into high and low leverage firms.

$$
\text { WACC }_{\mathrm{i}, \mathrm{t}}=\alpha_{0}+\alpha_{1} \text { CONSERV }_{\mathrm{i}, \mathrm{t}}+\alpha_{2} \text { VDISC }_{\mathrm{i}, \mathrm{t}}+\varepsilon_{\mathrm{li}, \mathrm{t}}
$$

WACC is the weighted average cost of capital $\left(\mathrm{K}_{\mathrm{e}} * \mathrm{~W}_{\text {Equity }}+\mathrm{K}_{\mathrm{d}} * \mathrm{~W}_{\text {Debt }}\right)$; where, $\mathrm{K}_{\mathrm{e}}$ is the cost of equity capital calculated using the capital assets pricing model developed by Sharp (1964). $\mathrm{K}_{\mathrm{d}}$ is the cost of debt calculated as:

$$
\left(\operatorname{COD}_{i, t}=\left[\text { InterestCost }_{i, t+1} \div \text { InterestBearingDebtOutstanding }_{i, t, t+1}\right] \times[1-\text { TaxRate }]\right) \text {. }
$$

CONSERV is the firm-year measure of conditional conservatism obtained using Khan and Watts' (2009) method. VDISC is the voluntary disclosure measured based on voluntary disclosure index constructed by Haddad (2005). The number in parentheses is the P-value.

** Significant at the 0.01 level (2-tailed).

* Significant at the 0.05 level (2-tailed).

${ }^{\mathrm{d}}$ According to (LM) test, the null hypothesis for pooled OLS regression for the high leverage sample is rejected, since the P-value is equal to (0.000). Thus, Hausman test should be run. According to Hausman test, the results revealed that the random-effect OLS regression is appropriate for the high leverage firms' sub-sample.

${ }^{\mathrm{e}}$ According to (LM) test, the null hypothesis for pooled OLS regression for low leverage sample is rejected, since the $\mathrm{P}$-value is equal to (0.003). Thus, Hausman test should be run. According to Hausman test, the results revealed that the random-effect OLS regression is appropriate for the low leverage firms' sub-sample.

${ }^{\mathrm{f}}$ According to Gujarati (2003), Durbin-Watson test to detect serial correlation is acceptable when its value lies between $(1.5<$ Durbin-Watson <2.5). So, it is correct to use the regression model represented in (Table 8)-Panel (B).

Finally, since this study adopted pooled and panel data analysis techniques in every step when testing all the hypotheses of this study, and according to (Gujarati, 2003) the main advantage of using panel data analysis technique over pooled data analysis technique is helping in generating more variability and efficiency as well as less collinearity with variables; the researchers have chosen to adopt an additional test in this study. This is carried out by using linear estimation after one-step weighting matrix utilizing of the sampled firms for the years (2009-2013) observations amounting to (260) observations after detecting the top and bottom $1 \%$ of observation for each of the study variables establish the robustness of the parametric results obtained from panel OLS regression. Table (9) shows that the results of linear estimation after one-step weighting matrix are similar to the panel OLS results 
reported in Table (5).

Table 9. Panel EGLS (cross-section weights) regression results for industrial companies (2009-2013), 260 firm-year observations

Dependent Variable: WACC

Sample: 2009-2013

Periods included: 5 Years

Cross-sections included: 57 Firms

Total panel (balanced) observations: 285

Linear estimation after one-step weighting matrix

\begin{tabular}{lllll}
\hline Variable & Coefficient & Std. Error & t-Statistic & Prob. \\
Constant & 0.1287 & 0.0132 & 9.7111 & $(0.000)$ \\
CONSEV & -0.0026 & 0.0002 & -10.208 & $(0.000)^{* *}$ \\
VDISC & -0.0495 & 0.0117 & -4.2298 & $(0.000)^{* *}$ \\
FS & -0.0118 & 0.0018 & -6.3987 & $(0.000)^{* *}$ \\
FL & 0.0345 & 0.0050 & -6.8644 & $(0.000)^{* *}$ \\
R $^{2}$ & 0.4314 & & & $1.839^{\mathrm{g}}$ \\
Adjusted- R & 0.4224 & & Durbin-Watson & \\
F-statistic & 48.368 & & stat & \\
Prob. (F-statistic) & 0.0000 & & & \\
\hline
\end{tabular}

The table reports the results of running the panel EGLS (cross-section weights).

$$
W_{\text {WCC }}=\alpha_{0}+\alpha_{1} \text { CONSERV }_{i, t}+\alpha_{2} \text { VDISC }_{i, t}+\alpha_{3} F S_{i, t}+\alpha_{4} F L_{i, t}+\varepsilon_{1 i, t} .
$$

WACC is the weighted average cost of capital $\left(\mathrm{K}_{\mathrm{e}} * \mathrm{~W}_{\text {Equity }}+\mathrm{K}_{\mathrm{d}} * \mathrm{~W}_{\text {Debt }}\right)$; where, $\mathrm{K}_{\mathrm{e}}$ is the cost of equity capital calculated using the capital assets pricing model developed by Sharp (1964). $K_{d}$ is the cost of debt calculated as .CONSERV is the firm-year measure of conditional conservatism obtained using Khan and Watts' (2009) method. VDISC is the voluntary disclosure measured based on voluntary disclosure index constructed by Haddad (2005). FS is the firm size expressed by the natural logarithm of total assets. FL is the financial leverage expressed by the total debt divided by the total assets. The number in parentheses is the P-value.

** Significant at the 0.01 level (2-tailed).

* Significant at the 0.05 level (2-tailed).

g According to Gujarati (2003), Durbin-Watson test to detect serial correlation is acceptable when its value lies between $(1.5<$ Durbin-Watson <2.5). So, it is correct to use the regression model represented in (Table 9).

\section{Conclusions}

The results revealed that accounting conservatism and voluntary disclosure have significant negative impacts on Jordanians firms' cost of capital. Furthermore, larger firms are less likely to have an accounting conservatism policy and have a higher level of voluntary disclosure, because the cost of external financing for larger firms is lower than smaller firms. On the other hand, disseminating and collecting more information are a costly exercise, where larger firms are able to bear such high costs, smaller firms may be hesitant to provide additional disclosure which might put them at disadvantageous competition. Across the sub-sample of high leverage firms, the results show that only voluntary disclosure has a significant negative impact on the firm's cost of capital. On the other hand, the results revealed that across the sub-sample of low leverage firms, only accounting conservatism has a significant negative impact on the firm's cost of capital. This result is derived from the notion that high leverage firms seek to reduce their monitoring costs through adopting various types of voluntary disclosure. 
Due to the inverse impact between voluntary disclosure and cost of capital, managers should be aware of the importance of providing additional information and relating that with economic benefits, particularly reducing the cost of capital.

Finally we encourage our colleagues to test whether our results are sector sensitive since our sample includes only industrial companies, and to review the results to examine the reasons behind the different results reached when we decomposed the sample into high and low size as well as high and low leverage which didn't confirm with the full sample results.

\section{References}

Ahmad, K., \& Nicholls, D. (1994). The impact of non-financial company characteristics on mandatory disclosure compliance in developing countries: The case of Bangladesh. Journal of Accounting Education and Research, 29(1), 62-77.

Al-Shiab, M. S. (2008). The effectiveness of International Financial Reporting Standards adoption on cost of equity capital: A vector error correction model. International Journal of business, 13(3), 271.

Altman, E. (1992). Revisiting the High-Yield Bond Market. Financial Management, 21(2), 78-92. Retrieved from http://www.jstor.org/stable/3665667

Artiach, T. C., \& Clarkson, P. M. (2011). Disclosure, conservatism and the cost of equity capital: A review of the foundation literature. Accounting \& Finance, 51(1), 2-49. http://dx.doi.org/10.1111/j.1467-629X.2010.00387.x

Ashbaugh-Skaife, H., Collins, D. W., \& LaFond, R. (2006). The effects of corporate governance on firms' credit ratings. Journal of accounting and economics, 42(1), 203-243. http://dx.doi.org/10.1016/j.jacceco.2006.02.003

Bagnoli, M., \& Watts, S. G. (2005). Conservative accounting choices. Management science, 51(5), 786-801. http://dx.doi.org/10.1287/mnsc.1040.0351

Basu, S. (1997). The conservatism principle and the asymmetric timeliness of earnings 1. Journal of accounting and economics, 24(1), 3-37. http://dx.doi.org/10.1016/S0165-4101(97)00014-1

Bertomeu, J., Beyer, A., \& Dye, R. A. (2011). Capital structure, cost of capital, and voluntary disclosures. The Accounting Review, 86(3), 857-886. http://dx.doi.org/10.2308/accr.00000037

Botosan, C. A. (1997). Disclosure level and the cost of equity capital. Accounting review, 323-349. http://www.jstor.org/stable/248475

Brealey, R. A., Myers, C. and Allen, F. 2011. Principles of Corporate Finance 10th edition: The McGraw-Hill Companies, Inc.

Breusch, T. S., \& Pagan, A. R. (1980). The Lagrange multiplier test and its applications to model specification in econometrics. The Review of Economic Studies, 47(1), 239-253. http://www.jstor.org/stable/2297111

Chan, A. L. C., Lin, S. W., \& Strong, N. (2009). Accounting conservatism and the cost of equity capital: UK evidence. Managerial Finance, 35(4), 325-345. http://dx.doi.org/10.1108/03074350910935821

Cuadrado-Ballesteros, B., Garcia-Sanchez, I. M., \& Martinez Ferrero, J. (2016). How are corporate disclosures related to the cost of capital? The fundamental role of information asymmetry. Management Decision, 54(7), 1669-1701. http://dx.doi.org/10.1108/MD-10-2015-0454

Depoers, F. (2000). A cost benefit study of voluntary disclosure: Some empirical evidence from French listed companies. European Accounting Review, 9(2), 245-263. http://dx.doi.org/10.1080/09638180050129891

Dumontier, P., \& Raffournier, B. (1998). Why firms comply voluntarily with IAS: An empirical analysis with Swiss data. Journal of International Financial Management \& Accounting, 9(3), 216-245. http://dx.doi.org/10.1111/1467-646X.00038

Easton, P., 2004, "PE ratios, PEG ratios, and estimating the implied expected rate of return on equity capital," Accounting Review 79, 73-95Working paper. University of Notre Dame and INSEAD. http://dx.doi.org/10.2308/accr.2004.79.1.73

Estrada, J. 2001, The cost of equity in emerging markets: A downside risk approach (II), Emerging Markets Quarterly, pp.63-72. https://doi.org/10.2139/ssrn.249579 
Firth, M. (1979). The impact of size, stock market listing, and auditors on voluntary disclosure in corporate annual reports. Accounting and Business Research,9(36), 273-280. http://dx.doi.org/10.1080/00014788.1979.9729168

Francis, J., LaFond, R., Olsson, P. M., \& Schipper, K. (2004). Costs of equity and earnings attributes. The accounting review, 79(4), 967-1010. http://dx.doi.org/10.2308/accr.2004.79.4.967

Gietzmann, M. B., \& Trombetta, M. (2003). Disclosure interactions: accounting policy choice and voluntary disclosure effects on the cost of raising outside capital. Accounting and Business Research, 33(3), 187-205. http://dx.doi.org/10.1080/00014788.2003.9729646

Gietzmann, M., \& Ireland, J. (2005). Cost of capital, strategic disclosures and accounting choice. Journal of Business Finance \& Accounting, 32(3-4), 599-634. http://dx.doi.org/10.1111/j.0306-686X.2005.00606.X

Guay, W. R., \& Verrecchia, R. E. 2007. Conservative disclosure. Available at SSRN 995562

Gujarati, D.N. 2003. Basic Econometrics, 4th Edition, Irwin/McGraw-Hill, U.S.A.

Haddad, A. E. 2005. The impact of voluntary disclosure level on the cost of equity capital in an emerging capital market: the case of the Amman stock exchange. Doctoral dissertation, University of East Anglia.

Haddad, A. E., AlShattarat, W. K., \& Nobanee, H. (2009). Voluntary disclosure and stock market liquidity: evidence from the Jordanian capital market. International Journal of Accounting, Auditing and Performance Evaluation, 5(3), 285-309. http://dx.doi.org/10.1504/IJAAPE.2009.026629

Hamdan, A. M. M. (2011). The impact of company size, debt contracts, and type of sector on the level of accounting conservatism: an empirical study from Bahrain. international Journal of Business and management, 6(7), 134-146. http://dx.doi.org/10.5539/ijbm.v6n7p134

Hamdan, A. M. M. (2012). Factors affecting accounting conservatism when preparing corporate financial reports: Evidence from Jordan. Jordan Journal of Business Administration, 8(1).

Haniffa, M. H., and Rashid, H. M. A. 2005. The determinants of voluntary disclosures in Malaysia: The case of internet financial reporting. Unitar E-Journal, 2(1), 22-42.

Harvey, C. R. (1995). Predictable Risk and Returns in Emerging Markets. The Review of Financial Studies, vol. 8, no 3, pp. 773-816. Accounting and Economics, 6, 185-204. http://dx.doi.org/10.1093/rfs/8.3.773

Hossain, M., Perera, M. H. B., \& Rahman, A. R. (1995). Voluntary disclosure in the annual reports of New Zealand companies. Journal of International Financial Management \& Accounting, 6(1), 69-87. http://dx.doi.org/10.1111/j.1467-646X.1995.tb00050.x

Jensen, M. C., \& Meckling, W. H. (1976). Theory of the firm: Managerial behavior, agency costs and ownership structure. Journal of financial economics, 3(4), 305-360. http://dx.doi.org/10.1016/0304-405X(76)90026-X

Khalifa, M., \& Ben Othman, H. (2015). The effect of conservatism on cost of capital: MENA evidence. Applied Economics, 47(1), 71-87. http://dx.doi.org/10.1080/00036846.2014.962223

Khan, M., \& Watts, R. L. (2009). Estimation and empirical properties of a firm-year measure of accounting conservatism. Journal of accounting and Economics, 48(2), http://dx.doi.org/10.1016/j.jacceco.2009.08.002

Kothari, S. P., Li, X., \& Short, J. E. (2009). The effect of disclosures by management, analysts, and business press on cost of capital, return volatility, and analyst forecasts: A study using content analysis. The Accounting Review, 84(5), 1639-1670. http://dx.doi.org/10.2308/accr.2009.84.5.1639

Lara, J. M. G., Osma, B. G., \& Penalva, F. (2011). Conditional conservatism and cost of capital. Review of Accounting Studies, 16(2), 247-271. http://dx.doi.org/10.1007/s11142-010-9133-4

Lintner, J. (1965). The valuation of risk assets and the selection of risky investments in stock portfolios and capital budgets. The review of economics and statistics, 13-37. https://doi.org/10.2307/1924119

Minton, B. A., \& Wruck, K. H. (2001). Financial conservatism: Evidence on capital structure from low leverage firms. http://dx.doi.org/10.2139/ssrn.269608

Mo, K. (2015). Dynamic Relationship Between Voluntary Disclosure And Conservatism. Journal of Applied Business Research, 31(4), 1377. https://doi.org/10.19030/jabr.v31i4.9324 
Poshakwale, S., \& Courtis, J. K. (2005). Disclosure level and cost of equity capital: evidence from the banking industry. Managerial and Decision Economics, 26(7), 431-444. 431-444. http://dx.doi.org/10.1002/mde.1256

Schauten, M., \& Blom, J. (2006). Corporate governance and the cost of debt. http://dx.doi.org/10.2139/ssrn.933615

Schipper, K. (1991). Commentary on analysts forecast. Accounting Horizon, 5(3), 105-121. https://doi.org/10.2307/1882010

Sharpe, W. F. (1964). Capital asset prices: A theory of market equilibrium under conditions of risk. The journal of finance, 19(3), 425-442. http://dx.doi.org/10.1111/j.1540-6261.1964.tb02865.x

Spence, M. (1973). Job market signaling. The quarterly journal of Economics,87(3), 355-374. https://doi.org/10.2307/1882010

Zalloum, N. O., Zerr, A. E. A., Razaq, A., \& Said, M. (2013). Degree of Disclosure and Conservatism in the Annual Financial Statements in Service and Industrial Public Shareholding Companies listed in Amman Stock Exchange. European Journal of Business and Management, 5(25), 27-40.

Zare, R., Heidari, Z., Salehi, M., \& Jourkesh, H. (2013). Disclosure, Conservatism and their Influence on Cost of Capital of the Companies Accepted by Tehran Stock Exchange (TSE). Research Journal of Applied Sciences, Engineering and Technology, 5(21), 5122-5127.

Zhu, F. (2009). Cost of capital and corporate governance: International evidence. University of Wisconsin, Milwaukee. 